\title{
Cikkismertetés: Miért nem tesznek többet a szegregált romák az egészségükért? Feltáró néprajzi kutatás Szlovákiából
}

\author{
Article review: Why don't segregated Roma do more for their health? \\ An explanatory framework from an ethnographic study in Slovakia
}

Ismertető: $\quad$ Orsós Zsuzsanna $\square$

PTE ÁOK Orvosi Népegészségtani Intézet, Pécs

Ismertetett cikk: A Belak, A Madarasova Geckova, JP van Dijk, SA Reijneveld. Why don't segregated Roma do more for their health? An explanatory framework from an ethnographic study in Slovakia Int J Public Health. 2018;63:1123 doi: 10.1007/s00038-018-1134-2

Beküldve: $\quad$ 2019. 01. 30.

doi: $\quad$ 10.24365/ef.v60i2.414

Kulcsszavak: Szlovákia; romaegészség; egészségegyenlőtlenség; adherencia; néprajzi tanulmány

Keywords: Slovakia, Roma health, health inequality, adherence, ethnographic study

A közleményben ismertetett vizsgálat egy szlovákiai, 260 fős, szegregált roma településen vizsgálta, hogy miért gyakoriak az egészséget veszélyeztető magatartásformák a szegregált romák körében, illetve, hogy az ott élő emberek miért nem követik a klinikai vagy népegészségügyi ajánlásokat.

Jól ismert, hogy a közép-kelet európai országokban élő roma kisebbségek egészségi mutatói lényegesen rosszabbak a többségi populációkénál. Ugyanakkor az életmódi tényezők vizsgálata pedig majdnem mindenhol azt mutatta, hogy ehhez igen nagy mértekben hozzájárul a többségi népességhez képest kedvezőtlenebb egészségmagatartás (pl. alkoholfogyasztás, dohányzás, egészségtelen táplálkozás). Míg a vizsgálatok egy része ezt azzal magyarázza, hogy a romák általában a legalacsonyabb társadalmi-gazdasági helyzetú réteghez tartoznak, több tanulmány is felhívta a figyelmet arra, hogy a szegregált romák körében az egészségmagatartás - vagy legalábbis annak több aspektusa is - eltérhet az általános népesség ugyanazon társadalmi-gazdasági helyzetű csoportjainak magatartásától. Bár vannak adatok és teóriák az etnikai alapú egészségegyenlőtlenségek kialakulásának okairól, mindmáig nincs olyan komplex magyarázat, ami megfelelően leírná a szegregált romák kedvezőtlen egészségmagatartásának determinánsait és ezek kölcsönhatásait.

A jelen közlemény egy 2004-2014-ig tartó, nagyobb longitudinális vizsgálat adatainak egy részét dolgozta fel, hogy azonosítsa azokat a helyi szintű mechanizmusokat, amelyek az egészséges életmódi ajánlásokhoz való adherencia hiányának hátterében állnak. A nagyobb vizsgálat a szegregált település szociográfiai leírását végezte el, néprajzkutatói módszerekkel vizsgálta az ott élők mindennapjait (különös tekintettel az egészséggel kapcsolatos jellemzőkre), valamint szisztémás orvosi-antropológiai interjúfelvétel történt, illetve az elsődleges interjúk elemzésére adott reflexiókat rögzítették. A bemutatott eredmények elsősorban a néprajzi adatok dokumentumelemzésén alapulnak (kutatói jegyzetek, hang- és videofelvételek).

Hét olyan mechanizmust sikerült azonosítani, amelyek a szegregált településen élő romák nem megfelelő adherenciájának okai lehettek, illetve elősegítették körükben a helytelen egészség- 
magatartás-formák melletti érvelést. A mechanizmusok egy csoportja magukhoz a szegregált roma emberekhez kötődik, más része viszont a velük kapcsolatban álló nem romákhoz. Az első csoportba tartozik (1) a romák körében tapasztalt szegénység, szegregáció és átlag alatti infrastruktúra, (2) az egészségmagatartásra vonatkozó alternatív roma ideológiák és gyakorlatok, (3) az önmagukat kizáró roma ideológiák és tévhitek (pl. a romák nem képesek bizonyos viselkedésre, tevékenységre), (4) a romák jelenlegi helyzetükhöz való szocializációja - elfogadás, hozzászokás, természetesnek tartás. Nem roma részről pedig jelentős szerepe van az alábbiaknak: (5) romaellenes ideológiák, tévhitek, (6) diszkrimináció, rasszizmus és a romák elégtelen támogatása, (7) a klinikai és népegészségügyi ajánlások restriktív aspektusai (az ajánlások követése a romák körében olyan érzést kelthet, hogy ez által életminőségük csökken - például krónikus betegségek menedzseléséhez szükséges táplálkozási változtatások kapcsán). A fenti tényezők között nagyon szoros, többoldalú kapcsolat van, hatásuk egymást erősíti, illetve egyes tényezők fennállása továbbiak kialakulásához vezethet (pl. az adott helyzethez hozzászokás erősítheti azt az érzést, hogy nem lennének képesek külső standar- dokhoz igazodni, illetve az alternatív roma magatartási módokba vetett hit megszilárdulását eredményezheti).

A fenti tényezőknek, illetve kölcsönhatásaiknak elemzése alapján a szerzők fontosnak tartják az érintett romákkal annak megvitatását, hogy egyes tipikus, identitással kapcsolatos adherencia-problémák nem kapcsolódhatnak-e szimbolikus erőszakhoz (pl. történelmileg a nem romák által a romákra „erőltetett” értékítéletekből fakadóan). Felvetik továbbá a helyi nem romáktól származó helytelen gyakorlatok, illetve előítéletek felszámolását célzó intervenciók szükségességét, valamint felhívják a figyelmet az alternatív roma magatartásformák megfelelő és komplex vizsgálatának szükségességére. Hangsúlyozzák továbbá, hogy a rasszista nem roma ideológiák a romák körében internalizálódva olyan etnikai alapú identitás kialakulását erősíthetik, amely különösen a klinikai vagy népegészségügyi ajánlásoknak megfelelő életmód roma standardok szerinti esetleges kedvezőtlen életminőségi hatásaival együtt, adherencia hiányában jelentős szerepet játszhat a döntéseikben (ami mindezidáig nem kapott megfelelő figyelmet és hangsúlyt).

\section{TANULSÁGOK A HAZAI SZAKEMBEREK SZÁMÁRA}

Magyarországon is számos roma ember él szegregált településen vagy településrészen, így a cikkben leírtak a hazai cigányság szempontjából is relevánsak. A legfontosabb üzenet az lehet, hogy a kedvezőtlen egészségmagatartáshoz vezető tényezők egymást erősítik, egymással szoros kölcsönhatásban vannak, és az érdemi változásokhoz az összes okot fel kell számolni. Lényeges, hogy a jól ismert tényezők mellett (pl. szegénység, diszkrimináció) figyelmet kell fordítani az eddig nem kellően tanulmányozott kérdésekre is (pl. a roma identitás és ideológiák, egészséggel kapcsolatos tévhitek kialakulását és fennmaradását befolyásoló tényezők). A cikk szellemisége határozottan azt a véleményt sugallja, hogy a roma népesség egészségi állapota nem egyszerüen a szegénység következménye, hanem ennél sokkal összetettebb és bonyolultabb problémáról van szó. 